KAROLINA GALEWSKA

Uniwersytet im. Adama Mickiewicza w Poznaniu

kgal@onet.pl

https://orcid.org/0000-0002-5223-1105
DOI: http://dx.doi.org/10.17651/ONOMAST.63.14

Onomastica LXIII, 2019 PL ISSN 0078-4648

\title{
TŁUMACZENIE CHIŃSKICH NAZW WŁASNYCH W UJECCIU KOGNITYWNYM
}

Słowa tematyczne: tłumaczenie nazw własnych, przekładoznawstwo kulturowe, gramatyka kognitywna, nieprzekładalność, językowy obraz świata

Problematyka z zakresu tłumaczenia użytkowych nazw własnych nie należy do głównych obszarów badań translatologicznych (por. Wolnicz-Pawłowska, 2014, s. 201-202). Najczęściej studia poświęcone są nazwom będącym elementem literackiego świata przedstawionego, szczególnie tym pojawiającym się w literaturze dziecięcej (por. Woźniak 2009-2010). Wydawać by się mogło, że przekład onimów nie należy do zadań przysparzających tłumaczowi większych trudności, skoro duża część nazw geograficznych czy imion ma swoje odpowiedniki $\mathrm{w}$ innych językach, a i pozostawienie nazwy w oryginalnej formie nie powinno mieć poważniejszych konsekwencji dla odbioru tekstu, biorąc pod uwagę rozpowszechnioną opinię, że nomina propria nie mają znaczenia (por. Lubaś, 1973, s. 18-19).

Dopiero stosunkowo niedawno zaczęto zauważać, że tłumaczenie nazw własnych jest - paradoksalnie — bardziej skomplikowane niż thumaczenie całych tekstów, między innymi dlatego że onimy są jednostkami silnie nacechowanymi kulturowo (Poluszyński, 2012, s. 44). Na gruncie przekładoznawstwa kognitywnego imiona własne są postrzegane jako jedne z jednostek, których „,kulturowa specyficzność (...) rodzi problemy przekładowe" (Hejwowski, 2004, s. 71). Stanowiska zajmujących się przekładem badaczy i praktyków oscylują między dwoma biegunami: od przekonania, że nazwy własne należy bezwzględnie tłumaczyć (por. Poluszyński, 2012, s. 43) do opinii, że nazw własnych przetłumaczyć się nie da i należy je zawsze przenosić do tekstu docelowego w niezmienionej formie (por. Wolnicz-Pawłowska, 2014, s. 201)1. Problem ten sprowadza się do sporu o właściwości klasy nomina propria, którego uczestnicy prezentują

1 Pomiędzy tymi biegunami sytuują się m.in. stanowiska dzielące nazwy własne na przekładalne i nieprzekładalne (por. Nowakowska-Kempna, 1979, s. 25-26).

This is an Open Access article available at: https://onomastica.ijp.pan.pl, https://rcin.org.pl 
równie skrajne koncepcje. Imiona własne bywają traktowane jako jednostki niezwykle bogate znaczeniowo lub leksemy puste semantycznie.

\section{TŁUMACZENIE NAZW WŁASNYCH}

Skoro samo zjawisko posiadania przez nazwy własne znaczenia jest złożone i wciąż należy do bardzo dyskusyjnych zagadnień teorii onomastycznej (Bogdanowicz, 2017, s. 17), nieuniknionym jest przeniesienie owych wątpliwości na refleksję dotyczącą tłumaczenia propriów. Jeśli 'tłumaczyć' znaczy „wyrazić w innym języku (czyli języku docelowym) to, co zostało wyrażone w języku źródłowym, z zachowaniem odpowiedniości semantycznej i stylistycznej" („Dictionnaire de Linguistique” 1973 za: Pieńkos, 2003, s. 20), to nasuwa się pytanie: które $\mathrm{z}$ treści konotowanych przez nazwy własne uznać za podstawę ustalania ekwiwalentu semantycznego ${ }^{2}$. Trudno powiedzieć, czy thumacz jest w stanie zawsze do tych treści dotrzeć, biorąc pod uwagę fakt, że nazwa własna „obrasta” w nie na gruncie danej kultury, a jej wartość semantyczna może być znana tylko użytkownikom danego języka.

Zgodnie z założeniami językoznawstwa kognitywnego ekwiwalencja w przekładzie ma dążyć do identyczności obrazowania (Tabakowska, 1990, s. 106). W tym ujęciu techniki mające na celu jedynie naśladowanie formy nazwy własnej, takie jak przeniesienie czy transliteracja, nie spełniają należycie swojej funkcji. Problem przekładu na języki posługujące się pismem logograficznym jest jeszcze bardziej złożony, ponieważ nazwy nie mogą zostać przeniesione bez modyfikacji do języka docelowego, w którym występują inne grafemy, tak jak to często ma miejsce w przypadku interakcji między językami opartymi na alfabecie łacińskim. Celem niniejszego artykułu jest prześledzenie technik tłumaczenia chińskich nazw własnych na język polski i angielski oraz określenie stosunku treści zawartych w nazwach wyjściowych (endonimach) i docelowych (egzonimach) ${ }^{3}$. Pogłębionej analizie zostaną poddane toponimy z przestrzeni miejskiej Pekinu. Wartość semantyczna nazw oryginalnych i ich obcojęzycznych ekwiwalentów zostanie porównana za pomocą narzędzi gramatyki kognitywnej Ronalda W. Langackera, które dotychczas były wykorzystywane do analizy treści pojęciowej nazw pospolitych.

2 W związku z kontrowersjami dotyczącymi znaczenia nazw własnych, dla niektórych badaczy w ogóle niemożliwe będzie ustalenie ekwiwalentu semantycznego nomen proprium.

3 Dla uzyskania pełnego oglądu specyfiki transferu między tymi językami omówiony zostanie również proces przeciwny, tj. adaptowanie europejskich nazw własnych w języku chińskim. 


\section{TŁUMACZENIE EUROPEJSKICH NAZW WŁASNYCH NA JEZYK CHIŃSKI}

Specyfika onomastykonu chińskiego sprawia, że tłumaczenie nazw własnych z języka chińskiego i na język chiński jest o wiele bardziej skomplikowane niż w przypadku analogicznego transferu między językami posługującymi się pismem alfabetycznym. Fakt, że większość chińskich onimów jest transparentna semantycznie, sprawia, że imiona własne funkcjonują w świadomości użytkowników języka na innym poziomie niż wśród przedstawicieli naszego (łacińskiego) kręgu kulturowego. W języku chińskim przypisanie obiektowi określonej nazwy służy nie tylko jego oznaczeniu, ale również charakterystyce jego cech. Dla użytkowników języka polskiego czy angielskiego nomina propria służą dzisiaj przede wszystkim do nazywania obiektu i w większości przypadków nie są postrzegane jako jednostki posiadające znaczenie leksykalne, gdyż współczesny użytkownik języków zachodnich nie umie odczytać treści, które dane nazwy wyrażały w momencie powstania (Kaleta, 2005, s. 16) ${ }^{4}$.

Od wieków Chińczycy borykają się z problemem adaptacji obcych nazw do swojego systemu językowego, ponieważ ,nigdy nie umiano rozwiązać problemu z zapisaniem słowa, którego nie da się rozłożyć na części znaczące” (Künstler 2000 za: Siniarski, Zajdler, 2011, s. 148). W związku z tym obce nazwy są najczęściej przenoszone do języka chińskiego na zasadzie adaptacji fonetycznej. Znaki pisma dobiera się w ten sposób, by ich wymowa przypominała wymowę oryginalnego wyrazu ${ }^{5}$. W tym celu próbuje się dostosować znaczenie semantemów, często w oparciu o tzw. etymologię ludową (Siniarski, Zajdler, 2011, s. 149). Dlatego na przykład onim 'Adam Mickiewicz' w thumaczeniu na język chiński to 'Yadang Micikaiweiqi' (亞當・密茨凱維奇). Warto jednak zauważyć, że tego typu nazwy osobowe są nienaturalne dla użytkowników języka chińskiego, w którym rzadko zdarzają się wyrazy dłuższe niż dwusylabowe.

Podczas adaptacji nazwy na język chiński tłumacz musi być szczególnie ostrożny, ponieważ rozważenia wymagają różnorodne aspekty nowo powstałej jednostki: jej brzmienie, znaczenie poszczególnych morfemów, znaczenie wynikające z kompozycji elementów składowych, forma graficzna, możliwe skojarzenia z homonimicznymi wyrazami itd. Tak skomplikowana procedura sprawia, że nie zawsze są to transformacje udane. Nietrafiona okazała się chociażby pierwsza chińska nazwa coca-coli (Koukekoula lub Kekoukela), która wiernie naśladowała angielską wymowę, ale konstruowane przez jej komponenty zna-

\footnotetext{
4 Jest to założenie odwołujące się do klasycznych, prototypowych nazw własnych.

5 Jak zaznacza M. Künstler, adaptacja taka dokonuje się najczęściej w wyniku arbitralnej decyzji użytkownika języka (Künstler 2000 za: Siniarski, Zajdler, 2011, s. 148-149), dlatego kwestia podobieństwa fonetycznego jest względna. Nierzadko uczący się języka chińskiego mają problem $\mathrm{z}$ rozpoznaniem nazwy pierwotnie europejskiej (obcej).
} 
czenie mogło być odczytywane jako 'kijanka gryząca wosk' (Siniarski, Zajdler, 2011, s. 159), co nie zachęcało do nabycia produktu. Sukces słodkiemu napojowi zapewniła dopiero druga (i obecna) nazwa '可口可樂 Kekoukele', która nie tylko przypomina brzmienie oryginału, ale i współgra z przekazywanym w języku chińskim znaczeniem, sugerującym coś przyjemnego w smaku. W wolnym tłumaczeniu na język polski nazwa odpowiada frazie 'może uszczęśliwić twoją buzię'.

Ustalenie chińskiego odpowiednika obcej nazwy jest zatem niezwykle trudne, ponieważ do jej zapisu trzeba użyć znaków chińskich, co od razu zaburza czystą referencję nazwy nieprzejrzystej semantycznie w języku wyjściowym (każdy znak to wyraz lub morfem niosący konkretne znaczenie). Nawet jeśli thumacz będzie chciał zachować etykietalny charakter onimu i odtworzyć w ekwiwalencie tylko brzmieniowy, formalny kształt danego imienia własnego, morfemy składające się na nazwę będą czytelne dla użytkownika języka chińskiego, onim będzie więc miał dla niego określone znaczenie leksykalne, co może być sprzeczne z intencją twórcy nazwy oryginalnej. Warto jednak pamiętać, że „zapis znakami pisma chińskiego użytymi fonetycznie tworzy sekwencje całkowicie dla Chińczyka niepojęte, trudne do zapamiętania i wymówienia” (Künstler, 2006, s. 70). Wobec wyżej zarysowanych trudności przyjęło się stosowanie takiego zapisu nazw obcych, który sugeruje jakieś znaczenie w języku chińskim i nie musi mieć ono żadnego związku ze znaczeniem oryginału (Künstler 2006: 70). Dla przykładu, chińska nazwa polskiej stolicy — ‘華沙 Huasha' — oznacza 'kwietny pył'. Przywołany urbonim przypomina inne nazwy chińskie w rodzaju ‘花石Huashi’: 'kwietny kamień' (Künstler, 2006, s. 71).

\section{TŁUMACZENIE CHIŃSKICH ANTROPONIMÓW I CHREMATONIMÓW NA JĘZYKI EUROPEJSKIE}

Przenoszenie chińskich nazw do języków zachodnich jest o tyle ułatwione, że można posłużyć się transkrypcją pinyin, czyli znormalizowaną metodą transkrypcji języka chińskiego opartą na alfabecie łacińskim. Tłumacz ma zatem do wyboru trzy metody stworzenia odpowiednika nazwy: pełne thumaczenie, transkrypcję lub połączenie tych dwóch technik (nazwa częściowo tłumaczona, częściowo transkrybowana).

Chińskie nazwy osobowe są najczęściej przenoszone do języków europejskich w formie transkrybowanej. Jak już zostało wspomniane, wszystkie imiona w języku chińskim są znaczące, podczas gdy w językach zachodnich etymologia imion najczęściej ma zatartą motywację, która bywa trudna do ustalenia nawet dla językoznawców (Künstler, 2006, s. 66). Można powiedzieć, że nazwy osobowe, szczególnie imiona, są odbierane przez użytkowników języka 
polskiego czy angielskiego głównie jako wyrażenia referencyjne, pozbawione znaczenia ${ }^{6}$. Tłumaczenie morfemów chińskich imion i nazwisk na języki europejskie prowadziłoby zatem do generowania nazw osobowych, które składają się z całkowicie transparentnych semantycznie wyrazów pospolitych, co jest dla Europejczyka zjawiskiem niecodziennym i zakłócałoby pierwszoplanową, referencyjną funkcję imion. Użytkownik języka z kręgu kultury zachodniej mógłby tym samym mieć wątpliwości co do statusu onimicznego danej nazwy, a to wiązałoby się z problemami komunikacyjnymi. Warto też zwrócić uwagę na fakt, że sama kolejność kompozycji członów chińskich nazw osobowych rodzi dylemat przekładowy, gdyż w chińskiej tradycji onomastycznej nazwisko poprzedza imię.

Ujęcie kognitywne wymaga od przekładu dążenia do ekwiwalencji na poziomie obrazowania. Problem polega jednak na tym, że każda nazwa własna w języku chińskim otwiera ścieżki mentalnego dostępu do wyjątkowo dużej liczby domen $^{7}$, podczas gdy ta sama nazwa transkrybowana nie otwiera właściwie żadnych domen dla użytkownika języka docelowego. W języku chińskim onimy oprócz znaczenia leksykalnego mają bogate znaczenia asocjacyjne. W porównaniu ze skojarzeniami ewokowanymi przez nazwy europejskie potencjał asocjacyjny nazw chińskich jest większy ze względu na dodatkowy „,czynnik sensotwórczy", jakim jest pismo i jego znaki. Na ową mnogość asocjacji wpływa przede wszystkim monosylabizm semantemów, który wiąże się z niewielką liczbą sylab w języku chińskim (około 400; przy uwzględnieniu różnic tonów, ok. 1,3 tys.), co z kolei prowadzi do częstej homofonii semantemów (Kałużyńska, 2007, s. 297). Dlatego poszczególne wyrazy w naturalny sposób budzą u rodzimego użytkownika języka dodatkowe skojarzenia z ich homofonami, rozszerzając w ten sposób pole semantyczne nazwy (Kałużyńska, 2007, s. 297).

Kolejnym elementem kompozycji semantycznej nazwy chińskiej jest forma graficzna znaku, która może nawiązywać do znaczenia morfemu lub poprzez swoje właściwości strukturalne budzić różnego rodzaju asocjacje (Kałużyńska, 2007, s. 297). Struktury myślowe, ewokowane przez formę danego imienia, w żaden sposób nie mogą zostać odtworzone w tłumaczeniu na język posługujący się pismem alfabetycznym. Przytaczanym przez badaczy przykładem złożoności chińskich nazw jest imię urodzonej w 1933 roku kobiety, Jieming (介

6 Chodzi tu przede wszystkim o imiona i nazwiska nieprzejrzyste strukturalnie. Część nazw osobowych w językach europejskich, szczególnie przezwiska, ma bowiem bardzo wyraźne znaczenia metaforyczne czy asocjacyjne.

7 Zdaniem Langackera (2009, s. 71) „terminem używanym w gramatyce kognitywnej w celu jednoznacznego odniesienia się do treści jest domena. Mówimy więc, że dane wyrażenie przywołuje zbiór domen poznawczych jako podstawę swojego znaczenia (czyli treść poddaną obrazowaniu)". O domenach i mentalnym dostępie do domen zob. Langacker, 2009, s. 71-84. 
明 $)^{8}$. Morfemy składające się na antroponim oznaczają kolejno: 'być pomiędzy czymś' i ‘jasny, pogodny’. Ich treść językowa nie jest jednak kluczem do odtworzenia znaczenia kryjącego się za nazwą. Zanim Jieming przyszła na świat, jej rodzice mieli troje dzieci, z których najstarszych dwoje zmarło. W chwili narodzin dziewczynka miała już tylko brata. Sytuacja rodzinna została symbolicznie odzwierciedlona $\mathrm{w}$ imieniu najmłodszej córki: znak jie składa się bowiem z elementu oznaczającego człowieka (人) oraz dwóch kresek, które odwrócone dają liczbę dwa (二). Można więc powiedzieć, że w wymiarze graficznym morfem jie przywołuje mentalnie dwoje ludzi. Z kolei elementy składowe znaku ming oznaczają kolejno: słońce (日) oraz księżyc (月), symbolizują zatem kobietę (dziewczynę) i mężczyznę (chłopca). Nosicielka imienia objaśniła jego etymologię w następujący sposób: „Urodziło się czworo dzieci. Dwoje zmarło, dwoje żyje. Jedna dziewczyna i jeden chłopak. Dlatego nazywam się Jieming" [tłum. K. G.]. Wydaje się oczywistym, że przytoczenie powyższego uzasadnienia bez rozległego komentarza na temat struktury poszczególnych znaków spotkałoby się z kompletnym niezrozumieniem użytkownika języka $\mathrm{z}$ łacińskiego kręgu kulturowego.

Jeśli chodzi o chińskie firmonimy, to podobnie jak w przypadku nazw osobowych, są one jedynie transkrybowane, podczas gdy, jak możemy się domyślać, w oryginale powstały jako jednostki mające wywoływać bogate i przede wszystkim pozytywne skojarzenia. Nazwy znanych chińskich firm telekomunikacyjnych są dla polskiego odbiorcy puste znaczeniowo. Nazwa koncernu Huawei (華為) w języku chińskim przywołuje następujące znaczenia: 'Chiny', 'wspaniały' czy ‘dobrze prosperujący'. Logo firmy nawiązuje do struktury pierwszego znaku nazwy, który w piśmie uproszczonym (华) zawiera w sobie element pochodzący od znaku oznaczającego kwiat (花). Z kolei nazwa marki Xiaomi ( 小米), odpowiadająca polskiemu leksemowi proso, przywodzi rodzimym użytkownikom na myśl obrazy walki zbrojnej i konotuje rewolucyjną siłę. Kojarzy się bowiem ze sloganem (小米加步槍 dosł. 'proso i karabiny') używanym w czasie wojny domowej przez komunistów, którzy uzbrojeni tylko w karabiny i proso pokonali pozornie silniejsze siły rządowe (You, 2010, s. 97). Nazwa przedsiębiorstwa informatycznego Lenovo, stworzona na potrzeby rynków zagranicznych, ma niewiele wspólnego z jej oryginalną wersją — ‘聯想 Lianxiang'. W języku chińskim taka struktura konotuje między innymi 'myślenie', 'kreatywność', 'łączność', 'zacieśnianie więzi', a użytkownikom zachodnim Lenovo może się kojarzyć jedynie z nowością (łac. novus, Abl. novo), choć chyba niewielu z nich łączy markę z taką etymologią nazwy. Nie ulega zatem wątpliwości, że transkrybowanie chińskich nazw osobowych i firmowych jest

\footnotetext{
8 Etymologię imienia kobiety przytaczam za: Tesone, 2011, s. 36.
} 
równoznaczne ze stratą znaczeń ewokowanych przez morfemy składające się na dany antroponim czy chrematonim. Trudno jednak wymagać od tłumaczy przekładu onimów, za którymi stoją tak bogate struktury pojęciowe, nieodnoszące się jedynie do kategorii przywoływanych przez znaczenie poszczególnych semantemów.

\section{TŁUMACZENIE CHIŃSKICH TOPONIMÓW NA JĘZYKI EUROPEJSKIE - ANALIZA KOGNITYWNA}

Tłumaczeniu podlegają najczęściej toponimy, które odnoszą się do obiektów charakterystycznych, rozpoznawalnych wśród obcokrajowców. Można wskazać dwa sposoby pełnego thumaczenia nazw chińskich: tzw. thumaczenia literalne, wierne, opierające się na znaczeniu wyrazów pospolitych tworzących nazwę własną, oraz tłumaczenia nieliteralne, wolne, niebędące dosłownym przełożeniem członów oryginalnej nazwy. Stosuje się także tłumaczenie jedynie tzw. członu identyfikującego nazwy, wskazującego na typ danego obiektu, w wyniku którego otrzymujemy nazwy typu Plac Tiananmen czy Beihai Park (ang.). Mimo iż w zachodnich toponimach ów człon, zwany też generycznym, zazwyczaj nie jest dany bezpośrednio, to użytkownicy języka mają świadomość, do jakiej kategorii nazw należy dane imię własne, z powodu zawartego w propriach tzw. minimum znaczeniowego o charakterze kategorialnym, tj. niewyrażonego wprost elementu semantycznego (Kaleta, 2005, s. 24).

W przypadku obcowania z nieznanym językiem i kulturą użytkownik nie posiada odpowiedniej wiedzy referencjalnej, wydawałoby się zatem, że potrzebne jest wyrażenie owego znaczenia ogólnego w sposób literalny, aby ułatwić mu posługiwanie się owymi onimami. W zetknięciu z nazwami zapisanymi w całości za pomocą transkrypcji pinyin polski czy angielski odbiorca może czuć się bezradny, jeśli kontekst nie podpowiada mu choćby, jakiego gatunku jest to nazwa własna, podczas gdy w oryginale chińskie nazwy charakteryzują cechy danego obiektu, jego funkcję czy położenie. Co ciekawe, tłumaczenie propriów jest sprzeczne $\mathrm{z}$ technikami adaptacji nazw promowanymi na arenie międzynarodowej. Egzonimizacja nazw geograficznych jest obecnie niepożądaną formą adaptacji obcych toponimów. ONZ stara się ją powoli wypierać z oficjalnego użycia, dążąc do ujednolicenia nazewnictwa geograficznego świata (Mandola, 2015, s. 83).

Poniżej zostanie przedstawiona analiza w pełni tłumaczonych toponimów chińskich, która ma na celu zaprezentowanie możliwości wykorzystania metodologii kognitywnej do badania przyczyn i skutków wyboru danych jednostek przekładowych na ekwiwalenty chińskich toponimów. Do analizy zostały wybrane nazwy najsłynniejszych atrakcji turystycznych Pekinu, które wraz 
z polskimi i angielskimi odpowiednikami ${ }^{9}$ zaprezentowano $\mathrm{w}$ tabeli 1 . Wartości semantyczne badanych jednostek zostaną przedstawione za pomocą profili wyobrażeniowych zgodnie z założeniem Ronalda W. Langackera, że znaczenie tkwi w konceptualizacji ${ }^{10}$ (Langacker, 2009, s. 70) i „składa się z treści pojęciowej oraz sposobu obrazowania tej treści" (Langacker, 2009, s. 70).

Określenie najsłynniejszego na świecie zabytku chińskiego - Wielkiego Muru - jest $\mathrm{w}$ oryginale złożone $\mathrm{z}$ innego przymiotnika. W dosłownym tłumaczeniu nazwa oznacza 'długi mur'. Przyjęcie się struktury z przymiotnikiem 'wielki' może wynikać ze specyfiki toponomastykonu europejskiego, w którym zwyczajowo nie używa się określeń długości w członach różnicujących nazw. W języku chińskim istnieje także druga, oboczna nazwa: Wanli Changcheng (dosł. 'długi mur o długości dziesięciu tysięcy mil'). Jej tłumaczenie byłoby jednak problematyczne, ponieważ dawna chińska jednostka długości li nie ma dokładnego ekwiwalentu w innych językach (odpowiadała zazwyczaj około pięciuset metrom). Co więcej, liczebnik wan jest używany także w znaczeniu metaforycznym. Oznacza wielką liczbę czegoś, zatem de facto nazwa miałaby oznaczać 'bardzo długi mur', a nie mur o konkretnej długości. Ponadto należy zauważyć, że w strukturze chińskich nazw geograficznych często występują liczebniki, podczas gdy w naszym kręgu kulturowym zdarza się to bardzo rzadko.

Tabela 1. Nazwy atrakcji turystycznych Pekinu oraz ich polsko- i anglojęzyczne ekwiwalenty

\begin{tabular}{|c|c|c|}
\hline Język chiński ${ }^{11}$ & Język polski & Język angielski \\
\hline $\begin{array}{l}\text { 長城 Changcheng (‘długi mur’)/ } \\
\text { 萬里長城 Wanlichangcheng (‘długi } \\
\text { mur o długości dziesięciu tysięcy mil’) }\end{array}$ & Wielki Mur & The Great Wall \\
\hline $\begin{array}{l}\text { 紫禁城 Zijincheng } \\
\text { ('purpurowe zakazane miasto') / } \\
\text { 故宫 Gugong } \\
\text { ('dawny pałac') }\end{array}$ & Zakazane Miasto & The Forbidden City \\
\hline $\begin{array}{l}\text { 頤和園 Yiheyuan } \\
\text { ('ogród pielęgnowania harmonii') }\end{array}$ & Pałac Letni & The Summer Palace \\
\hline $\begin{array}{l}\text { 明十三陵 Mingshisanling } \\
\text { ('trzynaście grobowców Mingów') }\end{array}$ & $\begin{array}{l}\text { Grobowce dynastii } \\
\text { Ming }\end{array}$ & The Ming Tombs \\
\hline
\end{tabular}

9 Do wskazanych nazw polskich i angielskich będę odnosić się zamiennie, tzn. traktuję je jako jeden punkt odniesienia, ponieważ thumaczenia te są wobec siebie symetryczne.

${ }_{10}$ W ujęciu Langackera konceptualizacja jest dynamiczna, interaktywna, obrazowa i wyobrażeniowa. Na ten ostatni wymiar składają się m.in. metafora, amalgamat, fikcyjność i konstruowanie przestrzeni mentalnych (Langacker 2009: 70).

11 Podane znaczenia morfemów chińskich oparte są na wolnym thumaczeniu; niektóre z nich mogłyby zostać przełożone za pomocą synonimicznych wyrażeń, np. 頣和園 Yiheyuan 'park pielęgnowania spokoju' itd. 
Nazwy polska, angielska i chińska wykorzystują tę samą bazę pojęciową ${ }^{12}$. Centralnym punktem profili wyobrażeniowych wszystkich wariantów nazwy jest mur, chociaż operują one zupełnie inną perspektywą. Jeśli przyjmiemy za Ronaldem W. Langackerem, że treść pojęciowa danego wyrażenia to scena, a obrazowanie to jej ogląd (Langacker, 2009, s. 85), to możemy stwierdzić, że w procesie thumaczenia nazwy Changcheng dochodzi do zmiany układu oglądu sceny ${ }^{13}$, czyli „relacji między «oglądającymi» i sytuacją «oglądaną»” (Langacker, 2009, s. 109). Określenie 'wielki' aktywuje mentalnie treść pojęciową inną niż przymiotnik 'długi'. Wyobrażeniowo pojęcie 'wielki mur' skupia naszą uwagę poznawczą na wielkich rozmiarach obiektu, zaś 'długi mur' na jego rozciągłości w przestrzeni. Tym samym pojęcie przedstawia inny punkt widzenia osoby oglądającej scenę. Przymiotnik 'wielki' może oznaczać punkt widzenia konceptualizatora, który objął wzrokiem całość obiektu i dokonał oceny jego rozmiaru. Taki obraz mentalny thumaczy geneza nazwy „zachodniej”, która powstała pod wpływem przesadzonych relacji podróżników na temat gabarytów budowli. Wcześniej, zanim ustaliła się konkretna nazwa, mur nazywany był po prostu 'chińskim'. Wydanie „National Geographic” z 1923 roku informowało, że Wielki Mur jest jedynym na świecie dziełem rąk ludzkich, które byłoby widoczne z księżyca (Hessler, 2007). Nazwa uwzględnia zatem również perspektywę wyobrażenia (oglądu) muru ,z lotu ptaka”.

W strukturze chińskiej nazwy zawarta jest z kolei perspektywa osoby doświadczającej, znajdującej się na budowli, budującej lub obserwującej ją w rzeczywistości. Osoba taka ogniskuje uwagę ${ }^{14}$ na pasie muru, ciągnącym się nieskończenie w obie strony. Nie może dostrzec jego początku ani końca z jeszcze innego powodu. 'Długi mur' dla chińskich budowniczych oznacza doświadczeniową ,długość znoju”, stawiania przez setki, a nawet tysiące lat obiektu o olbrzymim zasięgu. Symbolizuje nieprzerwane i „doniosłe” trwanie w kulturze jednej z najstarszych cywilizacji. Najprawdopodobniej dlatego w profilu chińskiej nazwy znalazła wyraz wyobrażeniowa długość obiektu, a centralną domeną, jaką aktywuje wyrażenie, jest właśnie atrybut kształtu budowli.

Tkwiące $\mathrm{w}$ omawianych wyrażeniach różne perspektywy oglądu prowadzą w ich obrazowaniu do zróżnicowanych kierunków skanowania mentalnego ${ }^{15}$,

12 Zestaw treści pojęciowych, które dane wyrażenie obiera za podstawę swojego znaczenia, Langacker nazywa 'bazą pojęciową' (Langacker, 2009, s. 100).

${ }^{13}$ Langacker porównuje konceptualizację do oglądu sceny. W takim ujęciu ,perspektywa jest układem oglądu, w skład której wchodzi przede wszystkim punkt widzenia” (Langacker, 2009, s. 109).

${ }_{14}$ Jeden z wymiarów obrazowania, ogniskowanie, obejmuje według Langackera „wybór treści pojęciowej do celów prezentacji językowej oraz konfigurację tej treści, którą można metaforycznie opisać jako rozróżnienie na plan pierwszy i tło" (Langacker, 2009, s. 88).

15 O skanowaniu mentalnym zob. Langacker, 2009, s. 55, 120-121. 
a co za tym idzie do różnych profili wyobrażeniowych (zob. rys. 1). Przedstawione schematy profili wyobrażeniowych uwypuklają różnice konceptualizacji nazw w następujących szczegółach: a) punktu widzenia (odniesienia) konceptualizatora (PW), b) skanowania mentalnego (SM), c) profilu sceny (wyobrażeniowy fragment muru). Pozornie ekwiwalentne nazwy są zatem wynikiem przeciwstawnych doświadczeń mentalnych ich twórców, ilustrujących ich „wewnętrzny” lub „zewnętrzny" punkt widzenia, sekwencyjne lub holistyczne (całościowe) skanowanie, co doprowadziło do profilowania w wyrażeniach 'części' lub 'całości'.

長城 Changcheng ('długi mur')

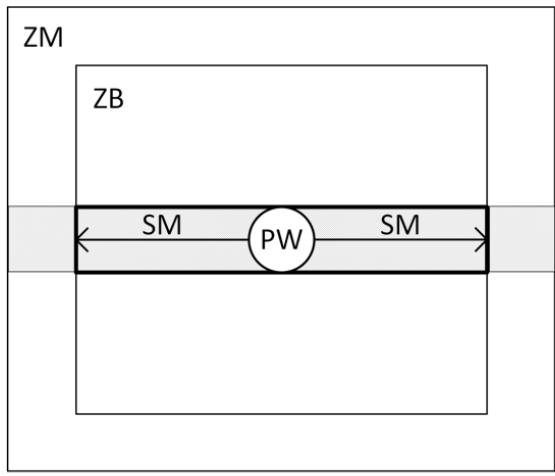

$$
\text { ZM - zakres maksymalny }{ }^{16}
$$

ZB - zakres bezpośredni
Wielki Mur/The Great Wall

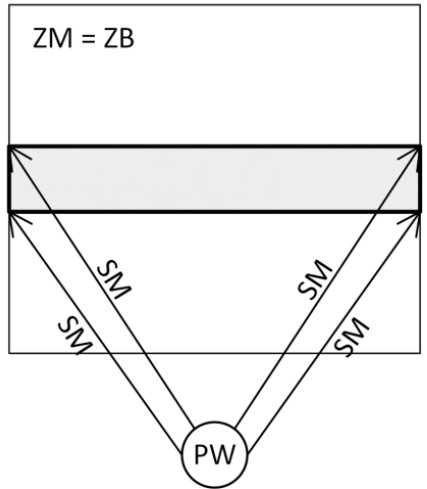

Rysunek 1. Schemat profili wyobrażeniowych nazw Wielkiego Muru ${ }^{17}$

Różne sposoby obrazowania sprawiają, że wartości konotacyjne nazw będą zupełnie inne dla użytkowników poszczególnych języków. Przymiotnik 'długi’ przywodzi chińskiemu użytkownikowi na myśl nie tylko kształt obiektu, ale także proces rozciągnięty w czasie, przypomina o uporze i wytrwałości jego budowniczych. Określenie 'wielki' również nie musi odnosić się tylko do rozmiaru obiektu. Wybór tego leksemu może być wyrazem podziwu, aprobaty dla po-

16 Pojęcia 'zakres' używam za R. W. Langackerem w znaczeniu: ,zakres informacji, jaką wyrażenie aktywuje w dostępnych domenach, czyli te części domen, które faktycznie przywołuje i wykorzystuje jako podstawę swojego znaczenia. (...) Zakres ma oczywistą podstawę poznawczą: istnieje tylko tyle treści, ile jesteśmy w stanie mentalnie ogarnąć w danej chwili” (Langacker, 2009, s. 95). Badacz dokonuje rozróżnienia między zakresem maksymalnym i bezpośrednim, czyli „pełną informacją, jakie dane wyrażenie zawiera, a (...) tą porcją informacji, jaka okazuje się bezpośrednio relewantna do realizacji określonego celu poznawczego" (Langacker, 2009, s. 96).

17 Zamieszczone $\mathrm{w}$ artykule schematy, inspirowane modelami zaproponowanymi przez R.W. Langackera (2009), zostały wykonane przez autorkę. 
tęgi i siły twórców budowli. Konotowane treści odzwierciedlają też omawianą różnicę przyjętych perspektyw: „,wewnętrznej” (narodu chińskiego) — w oryginalnej nazwie - i ,z zewnątrz" - w nazwach wygenerowanych z perspektywy zachodniej cywilizacji.

Onim Zakazane Miasto to thumaczenie pierwotnej nazwy obiektu Zijincheng. Pomija ono pierwszy człon oryginalnego imienia własnego, tj. przymiotnik ' $z i$ ' ('purpurowy'), który odnosi się do Gwiazdy Polarnej, w chińskiej astrologii określanej mianem $\mathrm{Zi}$ Wei. Ze względu na jej centralną pozycję w gwiazdozbiorze $Z i$ Wei nazywana jest także Cesarska Gwiazda (ang. the Emperor Star) i uważa się ją za symbol władcy, dlatego też została przywołana w nazwie posiadłości cesarza. W thumaczeniu element ten pominięto najprawdopodobniej z powodu niezrozumiałego dla Europejczyka odniesienia. Kompozycja kolejnych dwóch morfemów - jincheng — odnosi się do następujących znaczeń: obszar lub budowla o zamkniętym charakterze, miejsce niedostępne dla postronnych osób. Zestawienie 'zakazane miasto' jest ich wiernym tłumaczeniem. Nie ma ono jednak związku z obecnie używaną przez Chińczyków nazwą Gugong ('stary/dawny pałac').

Żadnego literalnego odniesienia do oryginału nie ma z kolei nazwa Letni Pałac. Tłumacz nawiązał tu do funkcji pełnionej przez obiekt, który był miejscem letniego wypoczynku cesarzy z dynastii Qing. W oryginale imię własne oznacza 'ogród pielęgnowania harmonii'. Takie tłumaczenie pokazuje, że niekiedy niezbędna jest całkowita zmiana elementów składowych (kompozycji) nazwy, co z kolei potwierdza tezę Romana Lewickiego (2010, s. 34), że ,asymetria pomiędzy nazwą oryginalną a nazwą stosowaną w tym samym odniesieniu przedmiotowym $\mathrm{w}$ języku docelowym niekiedy wynika z odmienności systemu semantycznego w języku docelowym (...). Jednak w znakomitej większości przypadków ma ona źródło kulturowe".

Obie nazwy, oryginalna i tłumaczona, zawierają w sobie inną konceptualizację tego samego wycinka przestrzeni. Pałac Letni to kompleks parkowo-pałacowy. Można więc powiedzieć, że obie nazwy mają ten sam zakres maksymalny oglądu ${ }^{18}$, w obrębie którego pojęcia chińskie i polskie/angielskie wysuwają inny element na plan pierwszy jako profil wyrażenia, czyli podstrukturę, na której jest skupiona uwaga poznawcza konceptualizatora (Langacker, 2009, s. $100)^{19}$. W nazwie Yiheyuan ogniskowanie prymarne dotyczy przestrzeni otaczającej obiekt, z kolei w nazwie Pałac Letni odnosi się do samego obiektu.

18 Jest to oczywiście pewne założenie, nie każdy obcokrajowiec wie bowiem, co wchodzi w skład kompleksu, jednak raczej wyobraża sobie pałac nie tylko jako konkretną budowlę, ale pewną posiadłość z otaczającym ją terenem.

19 Możemy także powiedzieć, że nazwy różnią się zakresem bezpośrednim. Langacker rozpatruje bowiem pojęcia 'zakres' oraz 'profilowanie' w kategoriach rozróżnienia między planem i tłem (Langacker, 2009, s. 96, 100-105). 


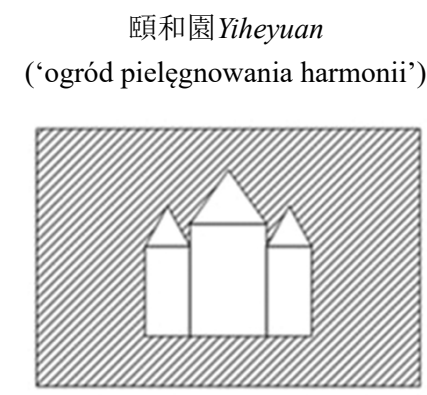

Rysunek 2. Zmiana profilu oglądu

Przedstawione na rysunku 2 profile wyobrażeniowe unaoczniają inny sposób percepcji zapisany w nazwach. Kreator nazwy chińskiej postrzega ogród jako figurę, a budowlę umieszcza $\mathrm{w}$ tle, $\mathrm{z}$ kolei twórca polskiego/angielskiego odpowiednika jako figurę pierwszoplanową profiluje pałac, a tłem ustanawia otaczającą go przestrzeń ${ }^{20}$. Domeny centralne, aktywowane podczas użycia chińskiej nazwy, w nazwie polskiej/angielskiej przesuwają się na peryferie i na odwrót. Nazwa chińska konotuje dominium związane z naturą, przestrzenią otwartą i wolnością, podczas gdy jej zagraniczne odpowiedniki przywołują siatki pojęć odnoszące się do cywilizacji, architektury, przestrzeni zamkniętej, zwierzchnictwa czy władzy (zob. rys. 3).

\section{頣和園Yiheyuan}

('ogród pielęgnowania harmonii')

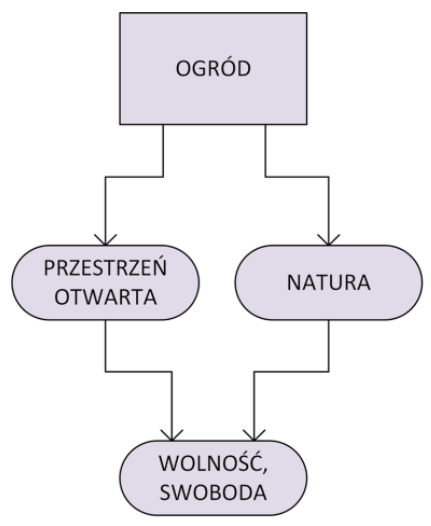

Pałac Letni / The Summer Palace

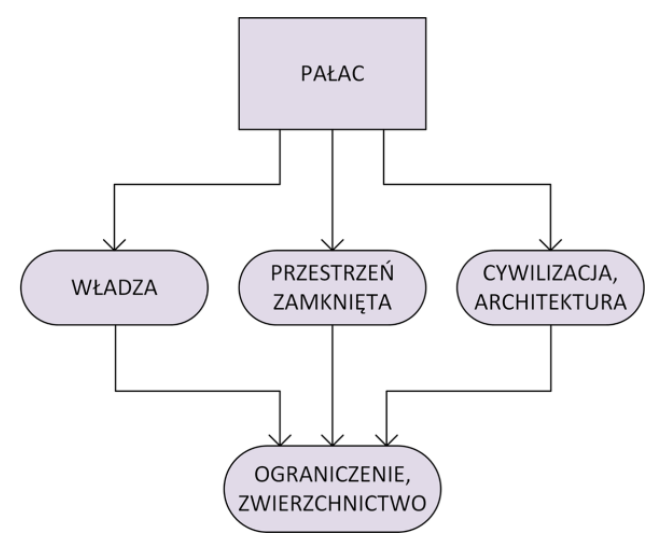

Rysunek 3. Schemat aktywacji zróżnicowanych domen

${ }^{20}$ Pojęciami ‘figura' i ‘tło' posługuję się za R.W. Langackerem (zob. Langacker, 2009, s. 89). 
Warto zaznaczyć, że w języku chińskim przydawka występuje w prepozycji w stosunku do określanego rzeczownika, co sprawia, że w ścieżce kompozycjonalnej ${ }^{21}$ wyrażenia 'ogród pielęgnowania harmonii' (w tłumaczeniu dosłownym: 'pielęgnowania harmonii ogród') na pierwszy plan wysuwa się znaczenie przydawki. Dla użytkowników języka chińskiego to atrybuty danego obiektu mają pierwszorzędne znacznie, o czym świadczy tworzenie kilkuelementowych struktur opisowych jako członów nazw własnych. Toponimy mają tu stałą strukturę: ,stojące zwykle na końcu jednosylabowe części generyczne (...) poprzedzane są częściami specyfikującymi, które w większości tworzą (niekiedy spiętrzone) struktury determinacyjne" (Künstler, 2006, s. 69-70).

Na terenie samego Zakazanego Miasta znajdziemy wiele innych tego typu nazw, jak np. Pałac Niebiańskiej Czystości, Pałac Doskonalenia Umystu czy Pałac Wiecznej Wiosny. Dlatego też tłumacz niekiedy musi zrezygnować z opisowej struktury chińskiej i odwołać się do funkcji danego obiektu. Decyzja taka prowadzi jednak do kształtowania się zupełnie innego krajobrazu językowego. Podczas gdy Chińczycy funkcjonują wśród nazw o bardzo wyraźnej funkcji estetycznej, wykreowany polski krajobraz językowy chińskich toponimów jest silnie nacechowany funkcjonalnością.

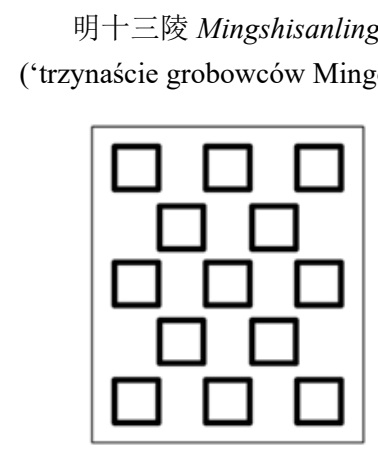

Grobowce dynastii Ming/ The Ming Tombs

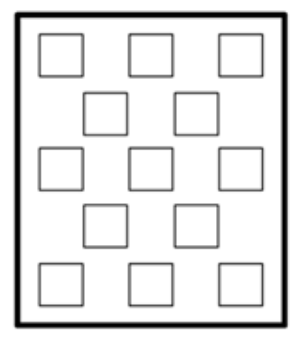

Rysunek 4. Zmiana uszczegółowienia profilu oglądu

W nazwie Grobowce dynastii Ming pominięto liczbę budowli zawartą w oryginale — trzynaście — która dla Europejczyka wydaje się zbędnym dodatkiem w nazwie obiektu turystycznego, a do tego, jak już wspomniano, brzmiałaby

${ }^{21}$ Za R.W. Langackerem posługuję się pojęciem ścieżki kompozycjonalnej jako relacji znaczenia wyrażenia złożonego do jego komponentów (Langacker, 2009, s. 93). Por.: „Należy pamiętać, że w gramatyce kognitywnej na znaczenie wyrażenia nie składa się jedynie złożona struktura semantyczna, ale również ścieżka kompozycjonalna, przy czym pozostają one do siebie w relacji figura - tło" (Langacker, 2009, s. 93). 
niezręcznie. Mamy tu do czynienia ze zmianą poziomu uszczegółowienia ${ }^{22}$, co prowadzi do zmiany profilu wyobrażeniowego nazwy (zob. rys. 4). Nazwa chińska wyróżnia de facto pojedyncze trzynaście grobowców wchodzących w skład zespołu, zaś nazwa polska/angielska konturuje i reifikuje pojęciowo zespół jako jedną całość, nie wyróżniając elementów składowych ${ }^{23}$. Nie dostarcza zatem dokładnych informacji o charakterze zbioru.

\section{PODSUMOWANIE, CZYLI O ZYSKACH I STRATACH}

Analiza wybranych thumaczeń chińskich nazw własnych, które są do języków europejskich przenoszone najczęściej na zasadzie transkrypcji, potwierdziła tezę, iż nie dysponując analogicznym repertuarem środków, nie sposób oddać w przekładzie na język angielski czy polski całej sieci pojęć, do których odwołują się kulturowo nacechowane wschodnie propria. Chińskie onimy z natury aktywują mentalnie więcej obrazów niż nazwy zachodnie, ponieważ ich struktura semantyczna, graficzna i foniczna może konotować niezależne treści. Można więc wysnuć ogólny wniosek, że w efekcie tłumaczenia nazw z języków europejskich na język chiński onimy zyskują dodatkowe znaczenia (generowane przez chińskie morfemy), które w świadomości użytkowników rodzimych nazw nie istnieją.

Z kolei w przekładzie z języka chińskiego nazwy zazwyczaj tracą znaczenia, które były im przypisane w oryginalnej wersji, choć w różnym stopniu, w zależności od zastosowanej techniki tłumaczenia. Transkrybowanie nazw, powszechne w przypadku antroponimów i chrematonimów, nie zachowuje żadnych treści konotowanych przez pierwotną nazwę. Częściowe thumaczenie (nazwa w połowie transkrybowana, w połowie thumaczona) daje użytkownikowi jedynie wiedzę, z jakiego typu obiektem ma on do czynienia, w pełni go jednak nie charakteryzuje, czym zubaża istotną $\mathrm{w}$ oryginale pierwotną strukturę semantyczną. Tymczasem thumaczenie pełne stanowi próbę wyeksponowania sensu danego onimu, co nie zawsze jest równoznaczne z pełnym transferem jego treści. Analiza kontrastywna wybranych nazw pokazuje, iż polskie i angielskie ekwiwalenty chińskich onimów nie oddają złożoności językowego obrazu świata chińskiego onomastykonu, który jest ściśle związany z tamtejszą historią, tradycją i filozofią. $Z$ treści konotowanych przez oryginalne propria wyłania się zupełnie inny obraz chińskiego narodu i jego kultury niż ten kreowany przez nazwy europejskie. W thumaczeniu zatracona zostaje, obecna w nazwach oryginalnych, bogata

22 O uszczegółowieniu zob. Langacker, 2009, s. 85-88.

${ }^{23}$ O konturowaniu zob. Langacker, 2009, s. 184; o reifikacji pojęciowej: Langacker, 2009, s. 133. 
symbolika liczb czy cała sfera aksjologii Dalekiego Wschodu, wyrażona m.in. w wartościach harmonii, wewnętrznej równowagi, pracowitości i umiłowania piękna.

\section{LITERATURA}

Bogdanowicz, E. (2017). Konotacje nazw własnych (na materiale publicystyki prasowej) [Connotations of Proper Names (Based on Press Publications)]. Białystok: Wydawnictwo Uniwersytetu w Białymstoku.

Hejwowski, K. (2004). Kognitywno-komunikacyjna teoria przekładu [The Cognitive-Communicative Theory of Translation]. Warszawa: PWN.

Hessler, P. (2007). Walking the Wall. Can one man's obsession solve the mystery of an ancient structure? The New Yorker [online]. Pobrano z: http://www.newyorker.com/ magazine/2007/05/21/walking-the-wall (dostęp: 6 IV 2017).

Kaleta, Z. (2005). Teoria nazw własnych [The Theory of Proper Names]. W: E. Rzetelska-Feleszko (red.). Polskie nazwy własne. Encyklopedia [Polish Proper Names. Encyclopaedia] (s. 15-36). Warszawa-Kraków: TNW - IJP PAN.

Kałużyńska, I. (2001). Współczesne chińskie nazwy miejscowe (nazwy miast i powiatów) — cechy strukturalne i semantyczne [Contemporary Chinese Place Names (Names of Cities and Districts) - Structural and Semantic Traits]. Onomastica, XLVI, s. 125-146.

Kałużyńska, I. (2007). Nowe zjawiska w dziedzinie chińskich nazw osobowych [New Phenomena in the Domain of Chinese Personal Names]. W: A. Cieślikowa, B. Czopek-Kopciuch, K. Skowronek (red.). Nowe nazwy własne - nowe tendencje badawcze [New Proper Names - New Research Trends] (s. 125-146). Kraków: PANDIT.

Künstler, M. (2006). O pewnych cechach specyficznych onomastyki dalekowschodniej [On Certain Specific Characteristics of Far Eastern Onomastics]. Onomastica, LI, s. 65-72.

Langacker, R.W. (2009). Gramatyka kognitywna. Wprowadzenie [Cognitive Grammar: A Basic Introduction]. Kraków: Universitas.

Lewicki, R. (2010). Niektóre kulturowe aspekty ustalania ekwiwalencji w przekładzie nazw własnych [Some Cultural Aspects of Selecting Equivalents in the Translation of Proper Names]. W: R. Lewicki (red.). Przekład — Język — Kultura II [Translation — Language — Culture II] (s. 31-38). Lublin: Wydawnictwo UMCS.

Lubaś, W. (1973). Onomastyka w systemie językowym (na przykładach słowiańskich) [The Onomastics in the Linguistic System (on Slavonic Examples)]. W: I. Bajerowa, W. Lubaś (red.). Prace Językoznawcze II (s. 7-25). Katowice: Uniwersytet Śląski.

Mandola, M. (2015). Egzonimizacja polskich toponimów w języku francuskim [Exonymisation of Toponyms of the Territory of Poland in French Language]. W: A. Gałkowski, R. Gliwa (red.). Mikrotoponimy i makrotoponimy w komunikacji i literaturze [Microtoponyms and Macrotoponyms in Communication and Literature] (s. 81-95). Łódź: Wydawnictwo UŁ.

Nowakowska-Kempna, I. (1979). Transpozycje nazw własnych z języka polskiego na języki południowo-słowiańskie [Transposition of Proper Names from Polish to the South Slavic Languages]. Katowice: Uniwersytet Śląski.

Pieńkos, J. (2003). Podstawy przekładoznawstwa. Od teorii do praktyki [The Basics of Translation: from Theory to Practice]. Kraków: Zakamycze.

Poluszyński, B. (2012). Strategie tłumaczeniowe stosowane podczas przekładu nazw własnych na przykładzie wybranych polsko-angielskich artykułów z Wikipedii (analiza jakościowa i ilościowa) [Translation Strategies Used in the Translation of Proper Names Based on the Polish-English Articles from Wikipedia (Qualitative and Quantitative Analysis)]. Języki Obce w Szkole, 4, s. 42-50. 
Siniarski, J., Zajdler, E. (2011). Kulturowy aspekt kodowania informacji w języku i piśmie — nazwy handlowe wiodących marek zagranicznych we współczesnym języku chińskim [The Cultural Aspect of Coding Information in Language and Writing: Names of the Leading Foreign Brands in the Contemporary Chinese]. W: E. Zajdler (red.). Zrozumieć Chińczyków: kulturowe kody społeczności chińskich [Understanding Chinese People: the Cultural Codes of Chinese Communities] (s. 131-174). Warszawa: Wydawnictwo Akademickie Dialog.

Tabakowska, E. (1990). Językoznawstwo kognitywne a poetyka przekładu [Cognitive Linguistics and Poetics of Translation]. Teksty Drugie, 3, s. 97-114.

Tesone, J.E. (2011). In the Traces of our Name. The Influence of Given Names in Life. London: Karnac Books.

Wolnicz-Pawłowska, E. (2014). Nazwy własne w przekładzie. Zarys problematyki [Proper Names in Translation. An Outline of Key Topics]. W: M. Graf (red.). Przestrzenie językoznawstwa. Prace dedykowane Profesor Irenie Sarnowskiej-Giefing [Spaces of the Linguistics: Studies Dedicated to Professor Irena Sarnowska-Giefing]. Poznańskie Spotkania Językoznawcze, 27, s. 201-214.

Woźniak, M. (2009-2010). Przegląd bibliograficzny polskich i wydanych w Polsce prac i artykułów o przekładzie literatury dziecięcej [A Bibliographic Overview of the Polish Articles on Children's Literature Translation]. Przekładaniec. A Journal of Literary Translation Studies, 22-23, s. 283-292.

You, X. (2010). Writing in the Devil's Tongue: A History of English Composition in China. Carbondale: Southern Illinois University Press.

\section{SUMMARY}

TRANSLATION OF CHINESE PROPER NAMES: A COGNITIVE APPROACH

The article focuses on the translation of non-literary Chinese proper names, a subject which to date has not enjoyed much research interest as a result of the common belief that proper names are untranslatable. The article discusses techniques used in the translation of Chinese anthroponyms, toponyms and brand names into Polish and English. The author refers to the strategies used in the process of transferring names to the target language and presents the consequences of applying given techniques from the cognitive perspective, which entails analysing the names in terms of their structure and meaning. Particular attention is paid to the connotations of the names, the impact they have on the speakers of a given language, as well as the mental images that can be derived from their structure. In the contrastive analysis of the names of tourist locations in Beijing and their Polish and English equivalents, the author applies the cognitive grammar approach as developed by Ronald W. Langacker. The image schemas of the names are used to present the distinct conceptualizations embodied in the names with the same references in different languages. One of the chapters describes how European names are adapted into Chinese. The study also provides an overview of the characteristics of the Chinese onomasticon, a factor which makes translation from Chinese to European languages particularly complicated. The observations made in the course of the analysis permit conclusions to be drawn on the linguistic worldview created by Polish, Chinese and English propria.

Keywords: cultural translation studies, translation of proper names, cognitive grammar, untranslatability, linguistic worldview 